\title{
高蔵寺ニュータウンの給水・排水系統と開発以前の地形との関連
}

\section{A Relationship between Characteristics of Natural Environments and Water Supply \& Drainage Network in Kozoji New Town}

\author{
芹沢 保教* 篠沢 健太 ${ }^{* *}$ 宮城 俊作** 城地 園子**** \\ Yasunori SERIZAWA Kenta SHINOZAWA Syunsaku MIYAGI Sonoko JOCHI
}

\begin{abstract}
The new town, built to respond for housing demand in high economic growth period, had been developed in hilly suburbs area. Development plans of such new towns seem to be related natural environments closely, especially to former, original landform. Kozoji New Town, located in northeast part of Nagoya metropolitan area, was one of such new towns in the hilly area. In this study, we focused on water supply and drainage system of Kozoji New Town, to examine the effect of original landform to the development plan and urban infrastructure of the NT. The drainage system and districts follow the former valleys and ridges, while the water supply system and districts distribute water in accordance with altitudes. We also identified modification of these systems, influenced by constructing highrise buildings on ridges. We concluded that characteristics of the infrastructure of Kozoji New Town are still related to former natural environment.
\end{abstract}

Keywords: Kozoji New Town, original landform, water supply system, drain system キーワード：高蔵寺ニュータウン、原地形、給水系統、排水系統

\section{1. 研究の背景、目的}

高度経済成長期，人口増加による住宅需要に対応するため郊外 に建設されたニュータウン (以下, NT と示す) の多くは丘陵地 を造成して開発された。とくに初期の NT 開発計画においては地 形条件の克服が大きな課題であり，計画にも自然環境の影響への 対応が伺える。日本初の大規模 NT である千里 NT では近隣住区 論を開発以前の地形（以下，原地形と示す） と対応させる計画設 計の対処が見られる 1)。1951（昭和 36）年, 名古屋都市圈の北東 $20 \mathrm{~km}$ 丘陵地に開発が開始された高蔵寺 NT では, 近隣住区論と は異なり, センターを核とし, 枝状にのびる都市軸に高層住宅, 都市施設を集約するために，原地形の尾根に都市軸を配置してお り地形との対応関係がある2)。

高蔵寺 NT の開発については, 高山英華がまとめた計画史 ${ }^{2)}$ 他, 高蔵寺 NT の造成前後の地形を $50 \mathrm{~m}$ メッシュ単位で比較し 土地造成と都市構造との関係を明らかにした山元（2009）3)の研 究などがあるが，高蔵寺 NT と自然環境との関係を直接扱った既 往研究は限られる。篠沢ら（2015）は, 高蔵寺 NT マスタープラ ンの変遷に地形・地質などの自然環境が及ぼした与えた影響を検 証した 4)。また芹沢ら（2015）は高蔵寺 NT の 2 団地を対象に, 自然環境の計画一の制約が宅盤造成や団地の住棟配置, オープン スペースの配置に及ぼした影響を検証した ${ }^{5}$ 。ただし, 高蔵寺 NT のインフラストラクチャと原地形との関連に着目した研究は多く ない。

本研究は，高蔵寺ニュータウンの給水・排水系統に着目し，原 地形が NT の空間構造だけでなく，都市インフラストラクチャに も内在しているか検証する。給排水計画については，個々の高蔵 寺 NT 開発計画は既往文献にまとめられているが，原地形と給 水・排水系統の関係を地図上で詳細に検証して, 原地形との関連 を明確にして，今後の NT の建て替えへの示唆を得ることが目的 である。

\section{2. 対象と研究方法}

高蔵寺 NT の給水・排水系統と自然環境との関係を読み解くた めに, NT 開発前の原地形 (1959 年春日井市作成 1:3000 地形図) と現在の給水系統 (2013 年春日井市作成 上水道管路図) - 排水 系統 (2013 年春日井市作成 公共下水道台帳) の図をそれぞれ比 較, 検証した。さらに, 計画当初 (1961年) の給水・排水系統図 6) と実施段階の給水・排水系統をそれぞれ比較し, 計画の変更点 を考察した。

\section{3. 給水系統の特徵}

\section{（1）愛知用水之高蔵寺 NT の関係}

名古屋近郊に NT 建設が構想された際, いくつかの開発候補地 の中から現在高蔵寺 NT が位置する春日井市が選ばれた理由の 1 つとして, 当時計画中だった愛知用水からの水源確保が挙げられ る。当時春日井市の水道は地下水を水源としていたため「既成市 街地で年々増加し続ける水需要に応えていくには限界があり（中 略）高蔵寺ニュータウン開発によって生じる新たな水需要に対す る水源を独自で確保寸ることは困難」7)だった。このため「この 地区を縦貫寸る愛知用水に水源を求めること」が決定された7)。

現在 NT の給水は NT 北西の「県高蔵寺浄水場導水ポンプ室」 (標高約 $83 \mathrm{~m}$ ) で愛知用水から取水され, 約 $500 \mathrm{~m}$ 東の「県高蔵 寺浄水場」（標高約 $126 \mathrm{~m}$ ）までくみ上げられている。

\section{（2） 3 つの給水地域区分}

浄水された水は各配水場から「自然流下式」で各家庭に給水さ れる 8)。NT 内は標高の順に高区，中区，低区の 3 つの給水区に 区分されている。各給水区への配水場もそれぞれ個別にあり，給 水区より標高の高い位置（高区配水場は高区，中区と低区配水場 は中区）に整備されている。

\section{（3）実施計画段階での給水区の変更}

自然流下によって高・中・低区の 3 配水区に給水を行う計画は, 実施計画段階での検討結果, 数力所で水圧不足が生じることが明

\footnotetext{
*工学院大学大学院工学研究科建築学専攻 *工学院大学建築学部 ***大奈良女子大学生活環境学部 **w*神戸市役所
} 
らかとなった 9)。一部には加圧装置の設置により対処し，残る部 分については配水区の変更が行われた 9)。配水区を変更した箇所 の詳細は，次のとおりである (番号は図—1 と対応)。

このうち(1)〜(3)の中区箇所を高区へ切替えと (4)〜 (7)の低区箇所を 中区へ切替えは，水圧不足が原因である 9)。(8)は従来 NT 開発 以前から春日井市水道を使用していた庄名・東山地区の一部を， 既設の市水道に追加している 9)。(10は認可申請時には給水経路が 第三工区を経由していたが，第三工区の開発が中止されたため, 経路を第二工区内に変更し，中区より高区に切替えた 9)。配水区 変更箇所の多くは配水区未端にあたることも確認できる。

\section{（4）原地形と給水系統の重ね合わせ}

原地形と給水系統を比較したところ，実施段階で給水区が変更 された箇所（1)～(7)）付近で尾根に沿って配置された給水管が確 認できた（図一2）。自然流下式の給水方法では、重力を利用して 給水し, 流末の水圧を得るため, 高い尾根に給水管を埋設して標 高差を用いていると考えられる。一方，谷に沿うものや谷をまた ぐように配置された給水管も見られた。原地形と給水系統との関 連だけでなく, 道路計画, 造成計画などの事情が個々の箇所で影 響していると考えられる。

さらに，実施計画段階で給水区が変更された箇所（1)～(7)）と 地形との対応を見ると，多くの箇所が原地形の尾根沿いにあるこ とが確認できる。前述のように排水区末端にあたるこれらの箇所 では標高が高くなおかつ高層住棟を集約配置することが水圧不足 の原因となり給水区が変更されたのではないかと考えられる。

\section{4. 排水系統の特徵}

\section{(1) 計画排水区}

高蔵寺 NT には，鯎（うぐい）川，大谷川，鎌芝川，繁田川の 4 つ河川水系と, 白山都市下水路, 身洗水路の 2 つ公共下水道 を流末とする，計 18 の計画排水区が設定されている。水系ごと に，鯎川排水区（第 $1 \sim 4)$, 大谷川排水区（第 $1 \sim 5)$, 鎌芝川排 水区，繁田排水区（第 $1 \sim 6)$ ，白山排水区，身洗排水区に分けら れている(図-3)。

\section{（2）計画排水区と原地形の関係}

\section{1）集水域と旧河川流域の対応}

計画排水区と原地形を比較すると（図一4），計画排水区の境界 がかつての尾根とおおよそ重なることが確認できた。計画排水区 の範囲は，原地形の尾根，谷の構造を反映させているといえる。

高蔵寺地区開発に関連した河川は，繁田川，大谷川（東大谷川 を含む)，鯎川，鎌芝川，身洗川の 5 河川である。

また，河川とは別に，雨水専用水路の公共下水道として，身洗 水路と白山都市下水路が整備・改修された。身洗水路は以前の身 洗川を改修，白山都市下水路は農業用の水路を繁田川に繋げるよ うに改修したものである。上記の河川と雨水専用水路は高蔵寺 NT 開発の際に「原則的には，管理者である公共団体によって造成に 先がけて順次改修」されていったが，多くの箇所では「現況の断 面補1)が比較的大きいことから, 地区の流出増にたえ」られたため,

「部分改修または暫定改修により河積を確保しながら造成工事を 拡大」した ${ }^{10)}$

2）雨水管，排水口と谷の対応

雨水幹線と比較的太い雨水管 (春日井市下水道台帳の雨水管の うち, 二重線で図示されていた雨水幹線), 排水口と, 原地形の谷 や水系との対応を調べた（図-4）。大谷第 1 排水区、繁田第 2 ・ 第 4 排水区，身洗排水区，鎌芝排水区では，雨水管と排水口が原 地形の谷部分，水系に沿うように配置されている。かつての尾根 を基淮に境界が設定された計画排水区では，排水区内の原地形の 谷に雨水が自然流下寸ると予想できる。これらの排水区では，か つての谷や水系を継承して雨水幹線や排水口が配置されていると
考えられる。

\section{5. 計画当初と実施の比較}

（1）高蔵寺 NT 計画当初 (1961) の給水計画と実施の比較(図—5)

1）給水関連施設の位置変更

高蔵寺 NT 計画当初（1961）の給水計画と実施段階を比較する と，計画当初から配水区域は高区，中区，低区の 3 区分に分けて 計画されていた。配水施設については, 高区と中区の配水池は,

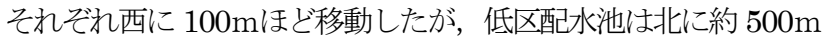
移動している。愛知用水からの取水位置は計画時, 実施段階とも NT 北西で同じ場所だったが，計画時に取水位置近くの低地に設 けられていた浄水場は, 実施段階では配水場近くに移動している。

1961 年計画時は, 低区配水場だけ, 高区・中区配水場と離れて 配置されていた。このため, 取水位置近くに浄水場を配置して浄 化し，浄水した水をそこから各配水場へ送る方が効率的だと考え られた可能性がある。一方, 実施段階では配水場が比較的近くに 集めて配置されたため，浄水場もそれらの近くに確保された。

2）給水区の変更箇所について

給水区は, 1961 年の計画当初, 基本計画段階, 実施計画段階の 3 回変更されている。最終の実施計画段階で低区から中区へ変更 された箇所の中には(図一5中(4)〜6), 1961 年の計画当初は中区 であり, 基本計画段階では低区となり, 実施計画段階で中区へと 変わっている。マスタープランの変遷によって, 給水区もその都 度変更があったと考える。

3）計画当初の給水区と原地形の関係

1961 年の給水計画と原地形の関係を見ると, 給水区が尾根の末 端を囲むように計画されている箇所が見られる（図－5）。計画当 初は比高の高い尾根に沿って給水系統を配置し, 給水する計画を 立案していたと考えられる。

\section{（2）高蔵寺 NT 計画当初 (1961) の雨水排水計画と実施の比較}

1）ため池について

1961 年の雨水排水計画（図一6）では，いくつかのため池が保 全されていた。雨水幹線はため池と接続されており，ため池は雨 水排水機能を保った遊水池として残そうとしていたことが考えら れる。実施段階ではほとんどのため池が埋められた。残った新池

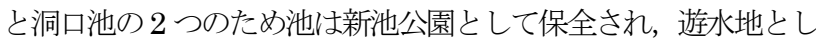
ての機能を果たしている。埋められたため池の中には，その後， 公園として整備されたものがいくつかある（図-4）。井戸坂池は 井戸坂公園, 石尾池は石尾公園として整備されている。公園内に 池や水系を確認することはできないが，公園の下にそれぞれ雨水 排水管が通っている。ため池としての機能は無くなったが，雨水 排水管が通過する場所して，原地形の水系の名残が公園の地下に 潜んでいると考えられる。

2）計画排水区の比較

高蔵寺 NT 計画当初（1961）の雨水排水計画と実施の比較をす ると，どちらも計画排水区の境界線が尾根に沿うに計画されてい て, 比較的同じ位置にある。1961 年の雨水排水計画より実施段階 の方が計画排水区を細かく分けている。細かく分けている部分も, 尾根に沿って計画されている。

\section{6. まとめ}

\section{（1）給水系統と原地形の関連}

高蔵寺 NT では，自然流下式で給水計画が計画されたため, 給水区分は標高に応じた高区，中区，低区と分けられていた。

給水区については，NT 計画当初の給水区は，実施段階の給水 区より尾根・谷を基準にして境界線を計画している。実施段階で の水圧不足が原因で給水区が変更された箇所は，原地形の尾根沿 いにあった。水圧不足は地形的な影響があると考えられる。 


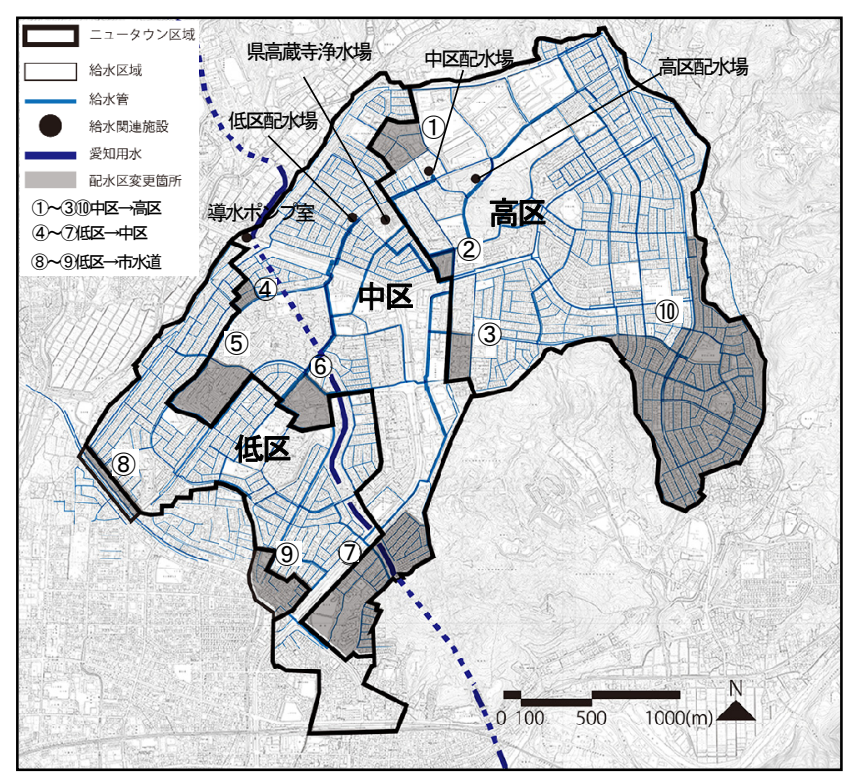

図—1 高蔵寺 NT の給水系統

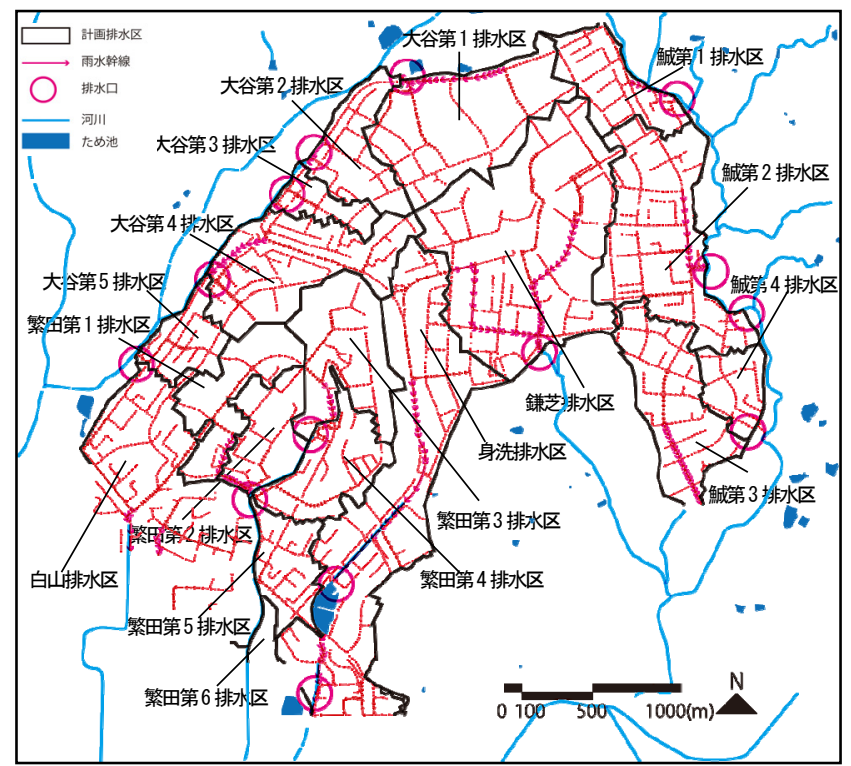

図—3 高蔵寺 NT の排水系統

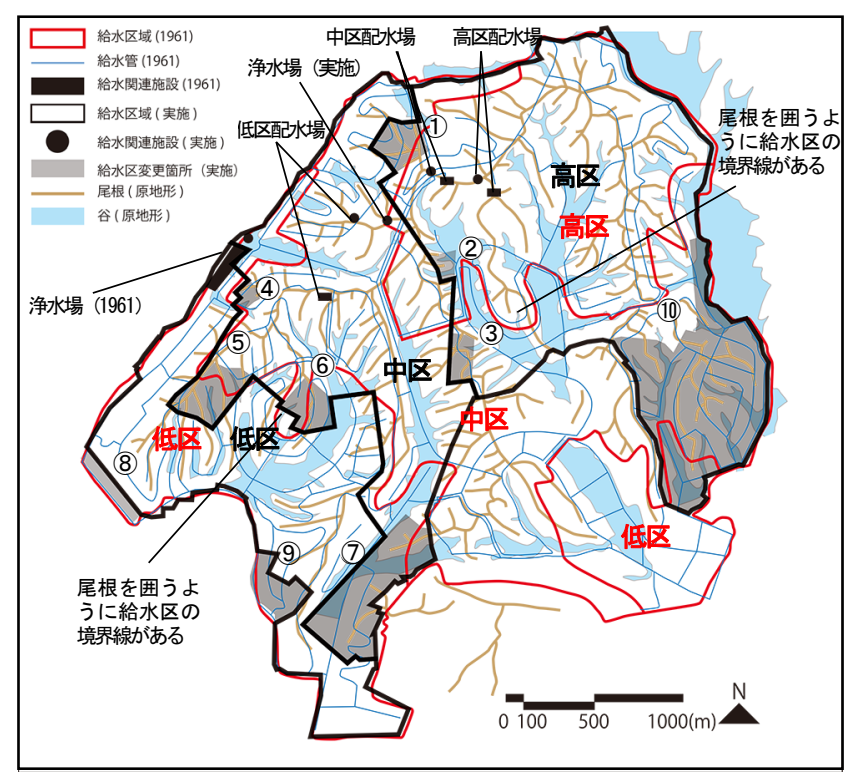

図—5 計画当初の給水区と原地形

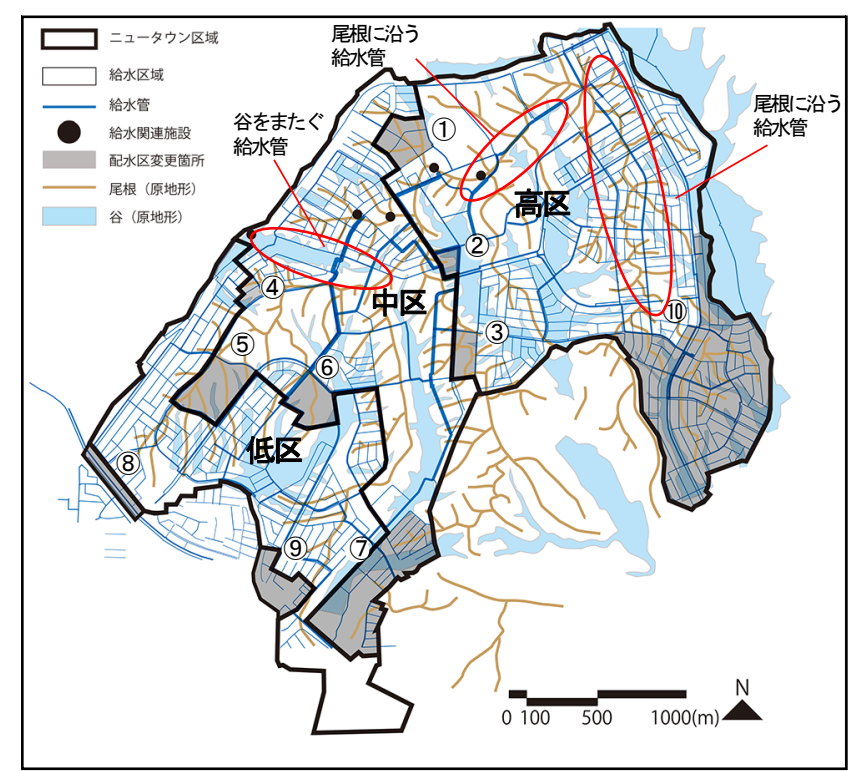

図—2 高蔵寺 NT の給水系統と原地形の関係

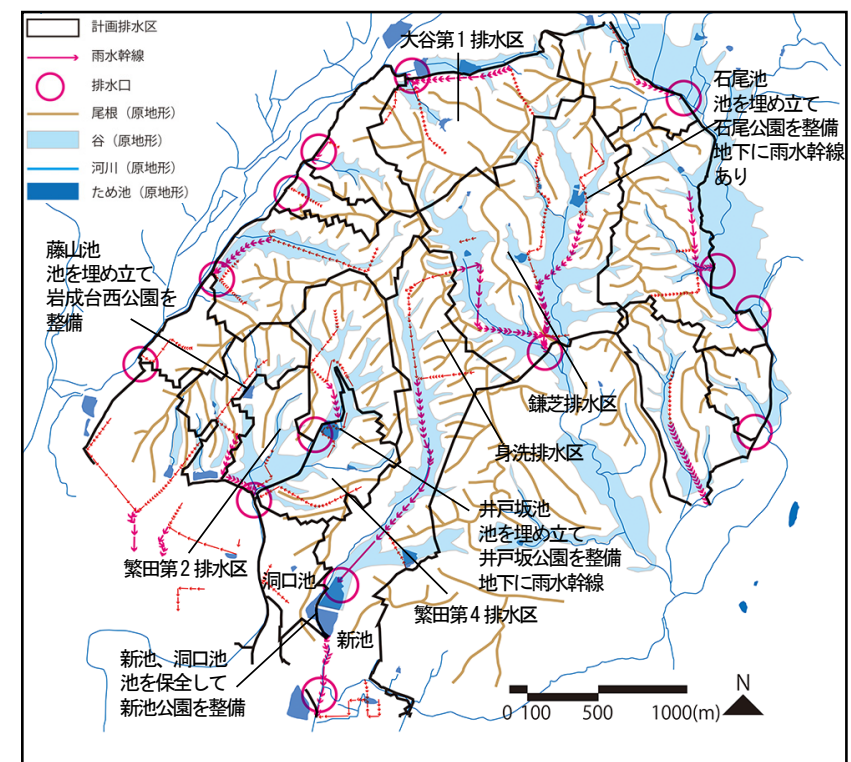

図—4 高蔵寺 NT の排水系統之原地形

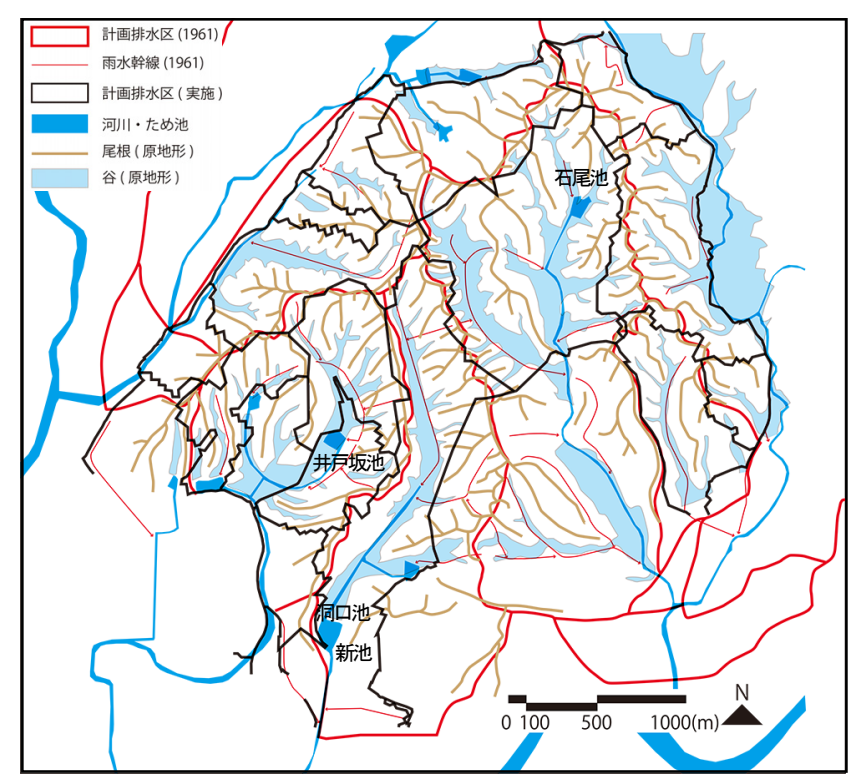

図—6 計画当初の排水区と原地形 


\section{（2）排水系統と原地形の関係}

排水計画では原地形の尾根・谷を基淮にして排水区の境界線が 引か氺，原地形の自然環境を反映した計画と言える。また，排水 口と雨水幹線が原地形の谷と水系に沿うものが多い。NT 内の排 水区が尾根・谷といったかっての集水域の自然環境を継承してい るだけでなく, 雨水幹線や排水口などの配置についても原地形や 水系との対応がみられた。さらに NT 計画当初の雨水排水計画と 実施の排水計画を比較すると, 当初の計画はため池を遊水地とし て多く残した雨水排水計画が行われていたが, 実施段階では新池, 洞口池のみが遊水機能を持った公園として保全された。実施で埋 められてしまったため池の中には, 公園として整備され, 公園の 地下に雨水排水管が通るものがみられた。ため池としては失われ てしまったが, 公園の地下に原地形の水系が潜んでいるといえる。

一見失われたかにみえる開発前の自然環境が，NT の空間構造 のみでなく, 都市施設・インフラストラクチャにも内在している ことが明らかになった。こうした計画されていることを考慮して, NT の再生や再編の時に, 開発前の自然環境と関連させた計画を 立てることが必要だと考える。

\section{7. おわりに}

高蔵寺 NT の給水区域や排水区域の範囲は，原地形の影響を受 けて計画していることが把握できた。さらに雨水排水管の埋設位 置は，原地形の水系や谷を反映していて，雨水排水系統に原地形 が内在していることも把握できた。

現在，老朽化した NT の建替え時期を迎えている。その再生 や再編の時に，NT の開発計画や開発前の自然環境との関係を把 握することにより，それらを基艋に再生計画がされることが望ま しいと考える。高蔵寺 NT は開発前の地形を基盤に計画され，現 在の都市空間に土地の自然環境が反映されていることが明らかに されている。本論で検討した給水・排水系統などの都市インフラ に関しても同様であった。単に新しい都市を計画したのではなく, 高蔵寺 NT の計画の特徴と計画と自然環境との関連を考慮して再 生や再編に活かせる部分があるかもしれない。

本論での検討を補完するために, 開発当時の計画・設計担当者 へのヒアリング調查を行う必要がある。今後の課題とさせていた だきたい。

また給水・排水系統の変更には原地形の影響以外に，NT マス タープランの変遷，道路・公園配置計画の変更が影響を及ぼして いることも考えられる。例えば一部の雨水排水系統は公園地下を 経由している。これらについても本論では検討しきれなかったた め, 今後の課題としたい。

謝辞: 本論を取りまとめるにあたって，元UR，元広島大学教授の 津端修一先生に多大なご指導を賜った。ここに記して感謝の意を 示寸次第である。なお本研究は科学研究費基盤(C)「ニュータウン に内在する自然環境を継承・再編するランドスケープ計画モデル の構築に関する研究」(課題番号 25450511) による研究の成果で ある。

\section{補注及び引用文献}

1）篠沢健太・宮城俊作・根本哲夫 : 2006 : 千里丘陵の開発における地形 の取り扱いと自然環境の構造:ランドスケーブ研究69(5) 817-822

2) 高山英華 (1967): 高蔵寺ニュータウン計画: 鹿島研究所出版会, 254pp

3) 山元貴継（2009）: 高蔵寺ニュータウンの開発と地形改変: 都市地理 学 4,51-61

4) 策沢健太・宮城俊作・城地園子(2015) : 高蔵寺ニュータウン開発計画 に及ぼした自然環樈構造の影響:ランドスケープ研究 78(5), 761-766
5）芹沢保教・篠沢健太・宮城俊作・城地園子(2015)：高蔵寺ニュータウ ンの住棟配置とオープンスペースにみる土地造成の特徵:ランドスケ 一プ研 究78(5), 773-776

6）日本住宅公団(1961）: 高蔵寺ニュータウン開発基本計画 $117 \mathrm{pp}$

7) 春日井市水道部監理課 (2007) : 春日井市水道事業 50 年史 みずとと もに 50 年 : 株式会社ぎょうせい, p 29

8）高蔵寺ニュータウン開発事業に係る事業記録編集委員会(1981): 高蔵 寺ニュータウン 20 年の記録: 日本住宅公団中部支社 73

9) 前掲書 8) , 73-79

10) 前掲書 8), p96

補注

補1）開発前の状況を示す。 